\title{
Who sells to the Soviet Union?
}

\section{The Reagan Administration will probably decide to extend the grain agreement with the Soviet Union for a year. Can it then insist that West European governments should not buy gas from the East.}

With the best will in the world, it will be hard for Europeans to be charitable about last week's special cabinet meeting called by President Reagan to help him decide whether United States farmers should continue to sell bulk cereals to the Soviet Union when present arrangements run out in September. Naturally, there will be much sympathy for Mr Reagan's dilemma. By denying it access to the Middle West, he could cause the Soviet Union a great deal of inconvenience (the need to shop around for other grain), physical discomfort (hunger) and even occasional starvation while establishing the powerful political point that United States farmers are more efficient than their Soviet counterparts. He would also provide the Soviet Union with a reminder that the de facto occupation of Afghanistan still rankles. These are great prizes, not lightly to be dismissed. But unfortunately for Mr Reagan, there is another millstone pressing on him - the unwillingness of farmers in the Middle West to sacrifice their occupations and their holdings by becoming bankrupt (more common already in the past twelve months than for several decades) in the cause of talking toughly to the Soviet Union. Politicians in most places will be full of fellow-feeling for the president. Especially because this is a mid-term election year (and because a decision must be made before polling day) they will weep with him as he sacrifices principles on the altar of prudence and renews the Soviet grain agreement for just one more year. But European politicians, no less given to calculations of how to square beliefs with the ballot box, will be asking why their acknowledgement of President Reagan's difficulty is not reciprocated in the matter of the natural gas pipeline between the Soviet Union and Western Europe.

That issue is more important than anybody in Washington seems to understand. (Mr George Shultz has made tactful noises, but is too new in his job as Secretary of State to be persuasive.) So far, three countries in Western Europe (France, Switzerland and West Germany) have committed themselves as customers for Soviet gas, and have agreed to make credits available for the construction cost of this gigantic project. (This in itself is not unusual; when did it most recently occur that Westinghouse, General Electric or Babcock-Wilcox built a nuclear power station in the hope of being able to sell the electricity production to some utility?) Sensibly enough, the countries concerned have done their best to ensure that they will not have to pay out too much (in the form of convertible currency) in advance by securing Soviet agreement to buy in much of the advanced equipment that will be needed. Washington has for the past six months been doing everything it can to ensure that such agreements will not be fulfilled - and that the Soviet Union will have to look to other suppliers or even make the equipment for itself. Since the summit meeting a few weeks ago at the palace of Versailles, the governments of Western Europe have been bubbling with resentment at President Reagan's Administration's ruling on this question. How can one government tell commercial corporations legally registered under another's laws that they should renege on what is otherwise a binding contract?

Western Europe's sin, on President Reagan's view, goes even deeper - its willingness to pay out convertible currency year after year in return for natural gas that may serve to keep its people warm and its industries in business but which will have the sideeffect of helping the Soviet Union to pay its bills and will make
Western Europe strategically dependent on the East for a substantial part of its energy consumption. When Washington first woke up to the problems of the pipeline project eighteen months ago, it was principally alarmed at the prospect of strategic dependence, now mercifully seen in a less clear light. The present concern seems principally to deplore any arrangement that will make it less likely that the Soviet Union will cease to function overnight, and which may even offer it some assurance of an income-stream for thirty years or so. The long-term nature of the pipeline agreement is admittedly a more solemn undertaking than the one-year extension of the grain agreement that Washington now contemplates, but Western Europe could presumably repudiate its inital investment in the pipeline if the going became rough (or the price of gas too high). President Reagan is probably under-estimating the friendliness of his friends in Western Europe (one disservice) and is certainly bullying them too much by his complaints about the pipeline (another).

All this is especially disconcerting at a time when the Reagan Administration is in the box of having to talk to the Soviet Union, most days at Geneva, about the future of strategic arms. That contradiction is awkward and not easily avoided. Washington needs a Moscow willing to talk about strategic arms, but properly insists on its right to be huffy about Afghanistan and other transgressions. It wishes that it could also afford the luxury - all those farming votes - of standing firm on principle. Detente, the saying seems to be, is from time to time an expedient necessity. Western Europe, on the other hand, with no choice but that of being within a few minutes (by Intermediate Range Ballistic Missile) from the border, believes and behaves differently. Interdependence is a fact of life, but does not preclude the sudden breakdown of coexistence. The wisdom of the pipeline deal, in other words, is judged by relatively short-term criteria; for a halfcontinent whose separate existence could be quickly ended, longterm economic deals (lasting, say, thirty years) count for less than longer-term cultural connections - the sense of deprivation springing from people's inability to visit European cities such as Prague, Warsaw or even Leningrad when they choose.

\section{Muddle about universities}

\section{The British government only seems to threaten university autonomy, but the precedent is bad.}

Is the independence of the British university system, traditionally assured by the existence of the University Grants Committee as an intermediary between the government and the universities, now threatened? This is the obvious question provoked by last week's open letter to the committee from Sir Keith Joseph, the Secretary of State for Education and Science in the British government. For the letter, described as the first exchange in a "dialogue" between the government and the universities, finishes with the declaration that, in the development of British higher education and of the universities in particular, "there will be some strategic decisions for which it would be appropriate for ministers to take explicit responsibility and to answer in Parliament". After more than two years of abysmal relations between the government and the universities that it supports, beginning with the decision in the summer of 1979 that 